\title{
ROLE OF DOMESTIC BIRDS IN TRANSMISSION OF ESCHERICHIA COLI AND SALMONELLA SPECIES AS A ZOONOTIC PATHOGENS
}

\author{
Mona Nasser", Adel El-Gohary ${ }^{* *}$ and Amro Mohamed** \\ *Veterinary medical Directorate, Dakahlia, General Organization of Veterinary Services (GOVS) \\ **Department of Hygiene and Zoonoses, Faculty of Veterinary Medicine, Mansoura University
}

\begin{abstract}
The role of domestic birds as a zoonotic reservoirs and sources of Escherichia coli (E. coli) and Salmonella species was investigated. For this purpose, a total of 442 samples were collected from 191 poultry (70 chicken, 51 ducks and 70 pigeons) and humans (25 stool specimens and 35 hand swabs). Concerning poultry samples, two samples (one cloacal swab and another feather) were taken from each bird. All samples were subjected for isolation and identification of E. coli and Salmonella spp., the recovered isolates were serologically typed. PCR technique was used for further characterization of some $E$. coli and Salmonella strains. Occurrence of $E$. coli isolated from cloacal swabs of birds was 37.4\%, while Salmonella spp.was $5.1 \%$. E. coli. Overall percentages of $E$. coli isolated from feather samples of birds was $37.4 \%$, meantime Salmonella spp. was 4.6\%. Regarding the isolated strains from human, E. coli isolated from hand swabs of poultry handlers was 20\%, and Salmonella spp. was 2\%. While occurrence of E. coli isolated from feacal samples of poultry handlers was $64 \%$ and Salmonella spp. was 4\%. The typed E. coli serotypes as O91:H21, were characterized strain EHEC (enterohemorrhagic E. coli), O2:H6, O78, O1:H7, O146:H21, O44:H18, O114:H4 and 0158 were strain characterized EPEC (enteropathogenic E. coli), O127:H6 were strain characterized ETEC (enterotoxigenic E. coli). It was concluded that domestic poultry in the examined areas considered a significant zoonotic reservoir for $E$. coli and Salmonella spp. Same serotypes and genotypes of $E$. coli and Salmonella spp. could be detected in both domestic poultry and humans, suggesting its zoonotic importance and these serotypes are circulated between domestic poultry and humans in the examined areas. The public health importance, healthy education as well as other precautions and preventive measures that recommended to the infection of such zoonotic bacteria in domestic birds and humans were fully discussed.

Keywords: Salmonella spp., E. coli, Serotyping, PCR.
\end{abstract}

\section{INTRODUCTION}

Poultry meat considered the most familiar in the market as it has more features than other meat as easy digestability, inexpensive and have great acceptance among the most of people (Lutful, 2010).

The importance of house breeding to farmers as a source of food in the form of meat and eggs and a source of employment, moreover source of income to the persons involved in poultry production. Poultry farming linked to rice farming which help controlling water snails and provide a good manure for fertilization of the soil in addition fish farming depends on poultry farming as poultry manure that help growth of phytoplanketon which considered a good source for fish feeding (Adziety et al., 2008). 
Zoonotic importance of Poultry to humans is dangerous as it transmits viral disease as avian infleunza and bacterial disease as E. coli, Salmonella spp., Proteus and Enterobacter. E. coli and Salmonella spp. causing public health hazard worldwide. In United States, $50 \%$ of human suffering from diarrhea caused by contaminated food by $E$. coli (Mead et al., 1999). In China $75 \%$ of morbidity in humans attributable to contaminated feed by Salmonella spp. (Bai et al., 2015). Multiplex PCR is a perfect tool for diagnosis of Salmonella spp. and Escherichia coli and for determining the virulence genes which has public health significance (Farooq et al., 2009 and Dutta et al., 2011). Multiplex PCR has been stratified to genus Salmonella and E. coli for detection of its toxins using highly conserved primers to recognize more than one target sequence in a single reaction (Alvares et al., 2004 and Cortez et al., 2006). Information about the potential role of domestic birds in maintaining and disseminating zoonotic agents in Egypt are little. From the zoonotic and economic impact of E. coli and Salmonella spp., this study was carried out to investigate bacteriologically and molecularly the role of domestic birds as zoonotic reservoir of E. coli and Salmonella spp. in Dakahlia governorate, Egypt.

\section{MATERIALS AND METHODS}

This study was performed to investigate the role of domestic poultry (chickens, ducks and pigeons) as zoonotic reservoir for pathogenic E. coli and Salmonella spp. by bacteriologically and molecularly approach.

\section{Sampling.}

A total of 442 samples were collected from poultry (382) and humans (60) from 37 farmers' houses of different villages, suburban and urban places of Mansoura, Dakahlia Governorate, Egypt.

\section{A. Bird samples:}

The samples represented cloacal swabs (191), feather swabs (191) of chickens (70), ducks (51) and pigeons (70.

\section{Cloacal swabs:}

Sterile swabs moistened in sterile BPW were inserted into the cloaca of bird and then withdrawn. The swabs were directly immersed into tubes contain BPW under aseptic conditions and transferred to the laboratory (Sadoma, 1997).

\section{B. Human samples:}

Human samples were collected from hand swabs (35) and stool specimens (25) of poultry handlers.

\section{Hand swabs:}

Sterile swabs moistened in sterile BPW were rolled against the dorsum and palm of the hand. The swabs were directly immersed into tubes contain BPW under aseptic conditions and transferred to the laboratory.

\section{Stool specimens:}

Sterile dry swabs were rolled in the stool specimens of human. The swabs were directly immersed into tubes contain BPW under aseptic conditions and transferred to the laboratory. 


\section{Bacteriological examinations:}

\section{A- Isolation of $E$. coli:}

Enrichment of the collected samples or swabs in BPW was carried out by incubation at $37^{\circ} \mathrm{C}$ for $18-24$ hours. After enrichment, a loopful from the incubated broth was streaked directly onto EMB (Eosin Methylene Blue) agar and incubated at $37^{\circ} \mathrm{C}$ for $18-24$ hours (Quinn et al., 1994). After incubation, the different representative colonies especially metallic shiny colonies from each plate were picked up, purified by streaking onto nutrient agar plates and incubated at $37{ }^{\circ} \mathrm{C}$ for $18-24$ hours. The purified colonies were streaked onto nutrient agar slants and incubated at $37{ }^{\circ} \mathrm{C}$ for 18-24 hours for further identification (Cruickshank et al., 1975). Meantime some identified colonies were preserved in glycerol.

\section{B- Isolation of Salmonella spp.:}

For isolation of Salmonellae, the collected swabs in BPW were pre-enriched by incubation at $37^{\circ} \mathrm{C}$ for 24 hours, after preenrichment, $0.1 \mathrm{ml}$ of pre-enriched cultured broth was inoculated into $10 \mathrm{ml} \mathrm{RV}$ broth and incubated at $41^{\circ} \mathrm{C}$ for 24 hours. After enrichment, a loopful from the enriched cultured broth was streaked onto XLD agar and incubated at $37^{\circ} \mathrm{C}$ for $18-24$ hours (Humphry et al., 1989). After incubation, (Red colonies with black centers) were picked up and streaked onto nutrient agar slants and incubated at $37^{\circ} \mathrm{C}$ for $18-24$ hours for further identification (Cruickshank et al., 1975). Meantime, some identified colonies were preserved in glycerol.

\section{3- Identifications of $E$. coli and Salmonella spp.:}

The isolated pure colonies from cloacal swabs and man were subjected to microscopical, biochemical and serological identification
Identification morphologically using microscopical examination and motility test according to MacFaddin (2000), while biochemical identification uses Indole test, Methyl Red Test, Voges - Praskauer test, Citrate utilization test, Urease test, Hydrogen sulphide production test, Gelatin hydrolysis test, Oxidation-Fermentation test, Nitrate reduction test, Detection of Ornithine decarboxylase (ODC), Detection of L- lysine decarboxylase (LDC), Detection of Arginine decarboxylase (ADH), Detection of $\beta$ galactosidase (ONPG), Fermentation of sugars were identified according to (Kreig and Holt, 1984).

\section{4- Serological identification:}

\section{A. Serological identification of $E$. coli:}

A total of representative $32 \mathrm{E}$. coli strains isolated from chickens (10), pigeons (6), ducks (10) and man (6) were subjected to serological identifications according to Kok et al. (1996) by using rapid diagnostic $E$. coli antisera sets (DENKA SEIKEN Co., Japan) for diagnosis of the Enteropathogenic types.

\section{B. Serological identification of Salmonella spp.:}

A total of representative 13 Salmonella strains isolated from chickens (4), pigeons (3), ducks (3), and man (3) were subjected to serological identifications according to Kauffman - White scheme (Kauffman, 1974) for the determination of Somatic (O) and flagellar (H) antigens using Salmonella antiserum (DENKA SEIKEN Co., Japan). 
5- Molecular identification of the isolated strains by multiplex-PCR:

A total of representative 23 (16 E. coli and 7 Salmonella spp.) biochemically and serologically identified strains (table 21 and table 22) were selectively subjected for molecular characterization by multiplex PCR.

Regarding, 10 strains of strains were assessed by multiplex PCR for stx2, stx1 and eaeA genes.

Concerning 5 strains of Salmonella were evaluated by multiplex PCR for invA, hilA and fim $H$ genes.

\section{A. DNA Extraction according to (Shah et al., 2009).}

Genomic bacterial DNA was extracted from the examined isolates using QIA amp kit according to (Shah et al., 2009).

\section{B. DNA amplification:}

\section{B.1. Amplification reaction of $E$. coli isolates (Fagan et al., 1999):}

The amplification was performed on a Thermal Cycler (Master cycler, Eppendorf, Hamburg, Germany). PCR assays were carried out using of nucleic acid template prepared by using reference EHEC isolates (approximately $30 \mathrm{ng}$ of DNA) and specific primers table (1).

Table (1): Primer sequences of $E$. coli used for PCR identification system:

\begin{tabular}{|c|c|c|c|}
\hline Target gene & Oligonucleotide sequence $\left(5^{\prime} \rightarrow 3^{\prime}\right)$ & $\begin{array}{c}\text { Product size } \\
\text { (bp) }\end{array}$ & References \\
\hline $\operatorname{stxl}(\mathrm{F})$ & $\mathbf{5}^{\prime}$ ACACTGGATGATCTCAGTGG '3 & \multirow{2}{*}{614} & \multirow{4}{*}{$\begin{array}{c}\text { Dhanashree and } \\
\text { Mallya (2008) }\end{array}$} \\
\hline Stxl (R) & 5' CTGAATCCCCCTCCATTATG '3 & & \\
\hline $\operatorname{Stx} 2(\mathrm{~F})$ & 5' CCATGACAACGGACAGCAGTT ' $\mathbf{3}$ & \multirow{2}{*}{779} & \\
\hline Stx2 (R) & $\mathbf{5}^{\prime}$ CCTGTCAACTGAGCAGCACTTTG ' $\mathbf{3}$ & & \\
\hline eaeA $(\mathrm{F})$ & 5' GTGGCGAATACTGGCGAGACT '3 & \multirow{2}{*}{890} & \multirow{2}{*}{$\begin{array}{c}\text { Mazaheri et al. } \\
\text { (2014) }\end{array}$} \\
\hline$e a e A(\mathrm{R})$ & $\mathbf{5}^{\prime}$ CСCCATTCTTTTCACCGTCG '3 & & \\
\hline
\end{tabular}

The conditions of amplification consisted of an initial $95^{\circ} \mathrm{C}$ denaturation step for $3 \mathrm{~min}$ followed by 35 cycles of $95^{\circ} \mathrm{C}$ for $20 \mathrm{sec}, 58^{\circ} \mathrm{C}$ for $40 \mathrm{~s}$, and $72^{\circ} \mathrm{C}$ for $90 \mathrm{sec}$. The final cycle was followed by $72^{\circ} \mathrm{C}$ incubation for $5 \mathrm{~min}$.
The reference strains were E. coli $\mathrm{O} 157: \mathrm{H} 7$ (positive for stx1, stx2 and eaeA) and E. coli (a nonpathogenic negative control strain) that does not possess any virulence gene. 
B.2. Amplification of virulence genes of Salmonella spp. (Singh et al., 2013):

The reaction mixes consisted of $5 \mu$ of the bacterial lysate, $5 \mu \mathrm{l}$ of $10 \mathrm{x}$ assay buffer for Taq polymerase containing $1.5 \mathrm{mM} \mathrm{MgCl} 2,2$ $\mu \mathrm{l}$ of $10 \mathrm{mM}$ dNTP mix $1 \mu \mathrm{l}$ each of forward and reverse primer (10 pmol) table (2) and 1.25 $\mathrm{U}$ of Taq DNA polymerase made up to $50 \mu \mathrm{l}$ using sterile distilled water. The PCR cycling protocol was applied as following: An initial denaturation at $94^{\circ} \mathrm{C}$ for $60 \mathrm{sec}$, followed by 35 cycles for $60 \mathrm{sec}$, annealing at $64^{\circ} \mathrm{C}$ for $30 \mathrm{sec}$ and extension at $72^{\circ} \mathrm{C}$ for $30 \mathrm{sec}$, followed by a final extension at $72^{\circ} \mathrm{C}$ for $7 \mathrm{~min}$. then electrophoresed in $1.5 \%$ agrose gel (Sigma USA), stained with ethidium bromide and visualized and captured on UV transilluminator.

Table (2) Primer sequences of Salmonella spp. used for PCR system:

\begin{tabular}{|c|c|c|c|}
\hline Target gene & Oligonucleotide sequence $\left(5^{\prime} \rightarrow 3^{\prime}\right)$ & $\begin{array}{l}\text { Product size } \\
\text { (bp) }\end{array}$ & References \\
\hline $\operatorname{inv} A(\mathrm{~F})$ & 5' GTGAAATTATCGCCACGTTCGGGCA '3 & \multirow{2}{*}{284} & \multirow{2}{*}{$\begin{array}{l}\text { Shanmugasam } \\
\text { y et al. (2011) }\end{array}$} \\
\hline $\operatorname{inv} A(\mathrm{R})$ & 5' TCATCGCACCGTCAAAGGAACC '3 & & \\
\hline hilA $(\mathrm{F})$ & 5' CTGCCGCAGTGTTAAGGATA '3 & \multirow{2}{*}{497} & \multirow{2}{*}{$\begin{array}{l}\text { Guo et al. } \\
\text { (2000) }\end{array}$} \\
\hline 9hilA (R) & 5' CTGTCGCCTTAATCGCATGT '3 & & \\
\hline $\operatorname{fim} H(\mathrm{~F})$ & 5' GGA TCC ATG AAA ATA TAC TC '3 & \multirow{2}{*}{1008} & \multirow{2}{*}{$\begin{array}{l}\text { Menghistu } \\
\quad(2010)\end{array}$} \\
\hline $\operatorname{fim} H(\mathrm{R})$ & 5' AAG CTT TTA ATC ATA ATC GAC TC '3 & & \\
\hline
\end{tabular}

Table (3): Occurrence of E. coli and Salmonella spp. isolated from cloacal swabs of birds.

\begin{tabular}{|c|c|c|c|c|c|c|c|}
\hline \multirow{2}{*}{$\begin{array}{c}\text { Source of } \\
\text { samples }\end{array}$} & \multirow{2}{*}{$\begin{array}{c}\text { No of } \\
\text { examined }\end{array}$} & \multirow{2}{*}{$\begin{array}{c}\text { No of } \\
\text { positive }\end{array}$} & \multirow{2}{*}{$*$} & \multicolumn{2}{|c|}{ E. coli } & \multicolumn{2}{|c|}{ Salmonella } \\
\cline { 5 - 8 } & & & $\begin{array}{c}\text { No. of } \\
\text { positive }\end{array}$ & $\%$ & $\begin{array}{c}\text { No. of } \\
\text { positive }\end{array}$ & $\%$ \\
\hline Chicken & 70 & 29 & 41.4 & 25 & 35.7 & 4 & 5.7 \\
\hline Duck & 55 & 17 & 30.9 & 14 & 25.5 & 3 & 5.5 \\
\hline Pigeon & 70 & 37 & 52.9 & 34 & 48.6 & 3 & 4.3 \\
\hline Total & 195 & 83 & 42.6 & 73 & 37.4 & 10 & 5.1 \\
\hline
\end{tabular}

*The percentage was calculated from each total bird samples. 
Table (4): Occurrence of E. coli and Salmonella spp. isolated from feather swabs of bird.

\begin{tabular}{|c|c|c|c|c|c|c|c|}
\hline \multirow{2}{*}{$\begin{array}{l}\text { Source of } \\
\text { sample }\end{array}$} & \multirow{2}{*}{$\begin{array}{c}\text { No of } \\
\text { examined }\end{array}$} & \multirow{2}{*}{$\begin{array}{c}\text { No of } \\
\text { positive }\end{array}$} & \multirow{2}{*}{$\% *$} & \multicolumn{2}{|c|}{ E. coli } & \multicolumn{2}{|c|}{ Salmonella } \\
\cline { 5 - 8 } & & & $\begin{array}{c}\text { No of } \\
\text { positive }\end{array}$ & $\%$ & $\begin{array}{c}\text { No of } \\
\text { positive }\end{array}$ & $\%$ \\
\hline Chicken & 70 & 33 & 47.1 & 29 & 41.4 & 4 & 5.7 \\
\hline Pigeon & 70 & 26 & 37.1 & 23 & 32.9 & 3 & 4.3 \\
\hline Duck & 55 & 23 & 41.8 & 21 & 38.2 & 2 & 3.6 \\
\hline Total & 195 & 82 & 42.1 & 73 & 37.4 & 9 & 4.6 \\
\hline
\end{tabular}

* The percentage was calculated from each total bird samples.

Table (5): Occurrence of enterobacterial strains in hand swabs of 35 poultry handlers.

\begin{tabular}{|c|c|c|c|}
\hline Isolated organism & Total no. of sample & NO. of positive & $\%$ \\
\hline E. coli & 35 & 7 & 20 \\
\hline Salmonella & 35 & 1 & 2 \\
\hline
\end{tabular}

Table (6): Occurrence of Enterobacterial strain in fecal sample of 25 poultry handlers.

\begin{tabular}{|c|c|c|c|}
\hline Isolated organism & Total no. of sample & No. of positive & $\%$ \\
\hline E. coli & 25 & 16 & $64 \%$ \\
\hline Salmonella & 25 & 1 & $4 \%$ \\
\hline
\end{tabular}

There are mixed infections of some examined samples serotypes. 
Table (7): Incidence of virulence genes of $E$. coli strains isolated from some representative examined samples isolated from bird, and human.

\begin{tabular}{|c|c|c|c|}
\hline E. coli strains & stx 1 & stx 2 & eaeA \\
\hline O1: H7 & - & + & - \\
\hline O2 : H6 & + & - & - \\
\hline O26 : H11 & + & + & + \\
\hline O44 : H18 & + & - & - \\
\hline $\mathbf{O 7 8}$ & + & - & - \\
\hline O91 : H21 & + & + & - \\
\hline O114: H4 & - & + & - \\
\hline $0127:$ H6 & - & + & - \\
\hline O146 : H21 & + & - & - \\
\hline 0158 & + & + & - \\
\hline
\end{tabular}

Stx1: Shiga- toxin 1 gene Stx2: Shiga- toxin 2 gene EaeA: intimin gene

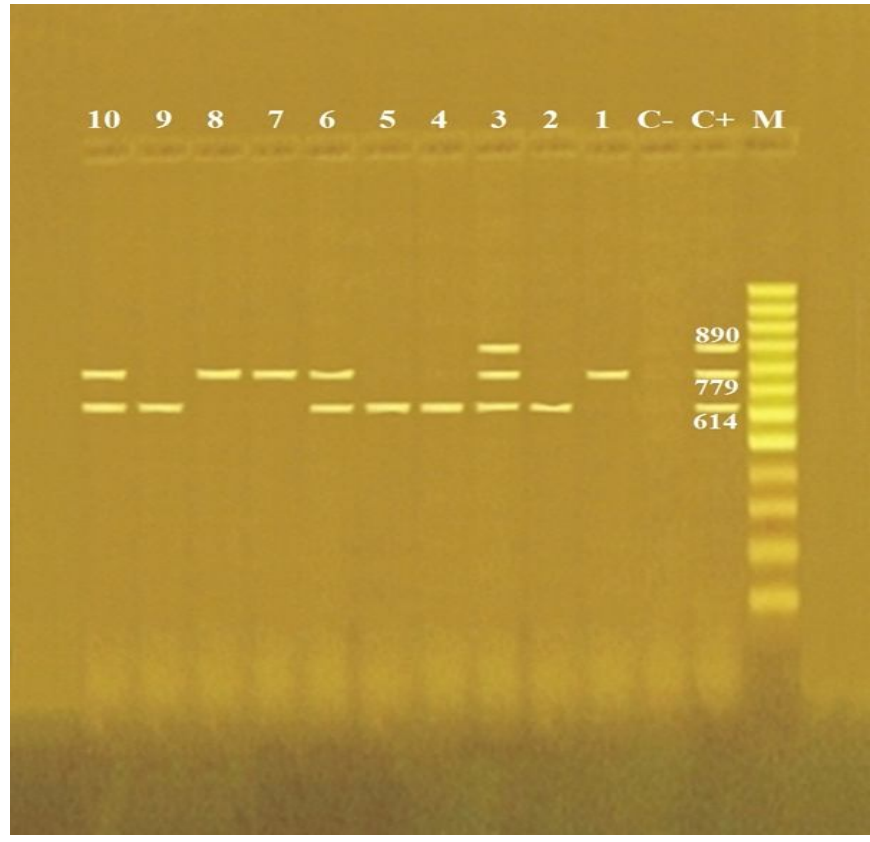

Photograph (1): Agarose gel electrophoresis of multiplex PCR of stxl, stx2 and eaeA genes for characterization of Enteropathogenic E. coli. E. coli showed bands for stxl at base pair 614 , for stx2 at base pair 779 and for eaeA at $890 \mathrm{bp}$.

Lane M: 100 bp ladder as molecular size DNA marker.

Lane C+: Positive control E. coli for stxl, stx2 and eaeA genes at 614, 779 and 890 bp respectively.

Lane C-: Control negative.

Lanes 2 (02), 4 (O44), 5 (O78) \& 9 (O146): Positive E. coli strains for Stxlgene.

Lanes 1 (O1), 7 (O114) \& 8 (O127): Positive $E$. coli strains for Stx2gene.

Lanes 6 (091) \& 8 (0158): Positive E. coli strains for stxl and Stx2gene.

Lane 3 (O26): Positive E. coli strain for stx 1 , stx 2 and eaeA genes. 
Table (8): Incidence of virulence genes of Salmonella strains isolated from some representative examined samples isolated from bird, and humans.

\begin{tabular}{|c|c|c|c|}
\hline Salmonella strains & inv $A$ & hilA & fim $\boldsymbol{H}$ \\
\hline S. Enteritidis & + & + & + \\
\hline S. Typhimurium & + & + & + \\
\hline S. Kentucky & + & + & + \\
\hline S. Inganda & + & - & + \\
\hline S. Takoradi & + & - & - \\
\hline
\end{tabular}

inv $A$ : invasion A gene hilA: hyper-invasive locus gene fimH: fimbrial gene

+ , presence of gene. - - absence of gene

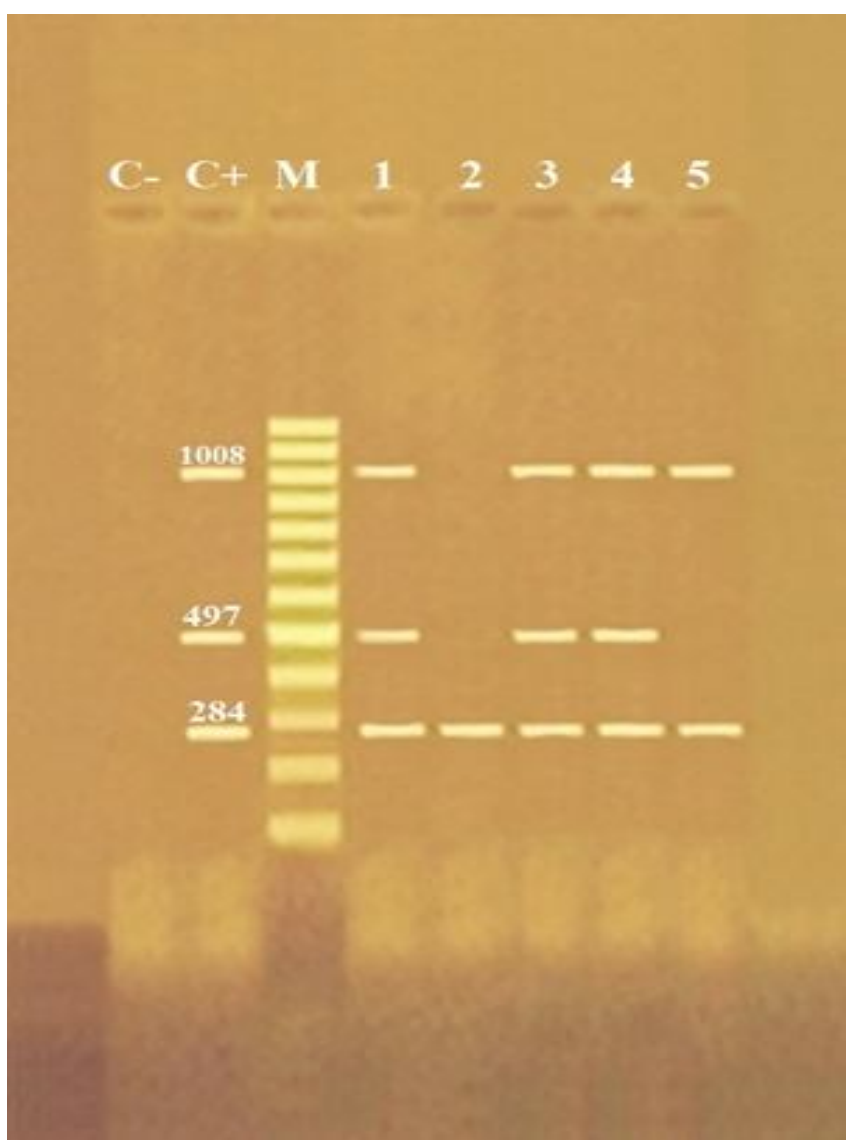

Photograph (2): Agarose gel electrophoresis of multiplex PCR of invA, hilA and fimH virulence genes for characterization of Salmonella species. Salmonella strains showed bands at 248bp for invA gene, $497 \mathrm{bp}$ for hilA gene, $1008 \mathrm{bp}$ for fimH gene.

Lane M: 100 bp ladder as molecular size DNA marker.

Lane C+: Control positive strain for invA, hilA and fimH genes.

Lane C-: Control negative.

Lanes 1 (S. Enteritidis), 3 (S. Typhimurium) \& 4 (S. Kentucky): Positive strains for invA, hilA and fimH genes.

Lane 2 (S. Inganda): Positive strain for $i n v A$ and fimH genes.

Lane 8 (S. Takoradi): Positive strain for invA gene. 


\section{RESULTS AND DISCUSSION}

In Egypt, the rapid growth of the poultry industry which considered to be a source of income to farmers in rural areas has resulted in the production of large quantities of poultry wastes and increasing contacts with birds may lead to spreading of zoonotic pathogens as $E$. coli and Salmonella spp. Avian pathogenic $E$. coli (APEC) infections are responsible for large economic perish to the poultry manufacture all over the world and there is increasing hazard of its zoonotic importance (Ashraf et al., 2013). Birds and birds products are considered to be the master provenance of non-Typhoidal serotypes of Salmonella enterica in the United States (Braden, 2006). Among the causative agent of foodborne pathogens, non-typhoidal Salmonella enterica is the main cause of morbidity and hospitalizations (Scallan et al., 2011)

From the ultimate importance of $E$. coli and Salmonella as causative agent of many gastrointestinal disease and illness in humans, this study was undertaken to search the role of domestic birds as zoonotic reservoirs and sources of such enterobacterial agents by microbiological and molecular assessment. One hundred and ninety-one poultry cloacal swabs (70 chickens, 51 ducks and 70 pigeons) were collected. Table (3) clarify the occurrence of Enterobacterial strains in poultry cloacal swabs. The overall percentages of the $E$. coli were 37.4 (73 out of 195). It was found that chickens, ducks and pigeons occurrence of $E$. coli, of $35.7 \%, 25.5 \%$ and $48.6 \%$, respectively. These results are nearly similar to the results previously reported by Taha (2002), Mondal et al. (2008), but were not similar to Hassan and Aml (2014) and Amira et al. (2017) Moreover, lower than the result reported by Halfaoui et al. (2017). Table (3) illustrate that 10 cloacal samples of poultry out of 195 samples were positive to Salmonella. The occurrence of Salmonella spp. has percentages of 5.7 for chicken, 5.5 for ducks and 4.3 for pigeons. These results are nearly similar to the results previously reported by other previous researchers (Mondal et al., 2008 and Amira et al. 2017), but were not similar to other authors (Ashraf and Tadashi, 2012 and Abdeen et al. 2018),). The results were lower than the results reported by Nógrády et al. (2008) and SeYeoun et al. (2013).

Regarding occurrence of $E$. coli in feather samples table (4) illustrate that $E$. coli isolated from feather samples of 70 chickens, 70 pigeons and 55 ducks with respective percentages of 41.4, 32.2 and 38.2. Table (4) show that occurrence of Salmonella spp. isolated from poultry feather samples of 70 chickens, 70 pigeons and 55 ducks with respective percentages of 5.7, 4.3 and 3.6.

Table (5) shows that E. coli was isolated from 18 out of 35 hand swabs $(51.4 \%)$. lower results were recorded by Heba (2003). Moreover, Mohamed et al (2004) identified E. coli from 6 of mother's hands with percentages of 18.8. In the current investigation, results recorded in table (5) show that the percentage of isolated Salmonella spp. from hand swabs of poultry handlers was 8.6 (three out of 35 ). Nearly similar result $(8.3 \%)$ was recorded by Mohammed et al. (1999). However, Sadoma (1997) and Heba (2003) isolated Salmonella spp. with percentages of $12.7 \%$ and $3.1 \%$. From zoonotic point of view, Salmonella can be directly transmitted to man through handling of infected birds because their feathers can harbor the infective organisms

Regarding the examinations of 25 human stool samples for the isolation and identification of Enterobacterial strains, table (6) shows the overall percentage of E. coli isolates was 64 (16 out of 25). Nearly similar 
results were obtained by Taha (1989) and Mohamed et al, (2004) who found that, E. coli comprised 52.6, 50\%, 64.3, respectively. Taha (2002) and Alizadeh et al. (2007) had all observed and reported less distribution of $E$. coli among man. However, lower results were obtained by Bodhidatta et al. (2002) who isolated $E$. coli from $6 \%$ of examined diarrheic cases. The high percentage occurrence of $E$ coli in man may be due to many factors, the most important of which is the fact that man live in contact with poultry; socio-economic level, environmental conditions, and low standard of sanitation and hygienic measurements are also other factors compromised in increasing the occurrence of $E$ coli infection.

Regarding occurrence of Salmonella spp. in human stool samples table (6) showed that. Salmonella spp. were isolated from $1(4 \%)$ out of 25 humans. This result was nearly to the result previously recorded by Mohamed et al (2004)

By serotyping of 36 isolates (12 chicken, 10 ducks, 8 pigeons and 6 humans) for identification of the isolated $E$. coli serotypes. the identified serotypes typed from birds and humans were $\mathrm{O} 78, \mathrm{O} 91: \mathrm{H} 21, \mathrm{O} 2: \mathrm{H} 6, \mathrm{O} 1: \mathrm{H} 7$, O158, O26:H11, O114:H4, O44:H18, O146:H21 and O127:H6 with respective percentages of $11,22.2,16.7,5.6,5.6,8.3,8.3$, 2.8, 13.9 and 5.6. There are two E. coli strains which isolated from hand swabs of poultry handlers serotyped as $\mathrm{O} 91$ and $\mathrm{O} 2$ with a percentage of 22.2 and 16.7, respectively. Regarding strain characterized of E. coli of some representative samples isolated from bird, and humans. Results show that E. coli serotypes as O91:H21, with characterized strain EHEC (enterohemorrhagic E. coli), O2:H6, O78, O1:H7, O146:H21，O44:H18, $\mathrm{O} 114: \mathrm{H} 4$ and $\mathrm{O} 158$ with strain characterization EPEC (enteropathogenic E. coli), O127:H6 with strain characterization ETEC (enterotoxigenic E. coli).
The identified Salmonella serotypes isolated from birds, and humans were $S$. Takoradi, $S$. enteritidis, $S$. Inganda, $S$. Typhimurium and $S$. Kentucky with respective percentages of 7.1, 35.7, 7.1, 35.7 and 14.3. Regarding the Salmonella serogroups identified from chicken samples, the results proved that $S$. enteritidis, $S$. Typhimurium and S. Kentucky were among the identified serotypes. Similar the results were previously recorded by $\boldsymbol{O r j i}$ et al. (2005), Ashraf and Tadashi (2012), Nagwa et al. (2012) and $\underline{\text { Abdeen }}$ et al. (2018). Moreover, Amira et al. (2017) identified same serotypes from chickens in Egypt including $S$. Kentucky with percentage of 6.7. Regarding the serotyping of three representative Salmonella strains isolated from humans, two stool samples and one hand swabs of poultry handlers, results shows that Salmonella isolated from stool samples were allocated to Salmonella Enteritidis (7.1\%) and Salmonella Typhimurium (7.1). While the serotype identified from hand swab was Salmonella Enteritidis (7.1). These results coincide with results obtained by Maysa et al (2013) and Nagwa et al. (2012) who isolated Salmonella Typhimurium from chicken samples and stool samples of humans. S. Takoradi among the isolates belonged to serogroup $\mathrm{C} 2$, with antigenic structure (O 8,20 and $\mathrm{H}$ i:1,5), $S$. Enteritidis belong to serogroup D1, with antigenic structure (O 1,9,12 and $\mathrm{H}$ g,m:-), moreover $S$. Inganda belong to serogroup $\mathrm{C}$,

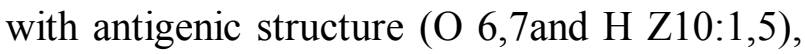
while $S$. Typhimurium belong to serogroup $\mathrm{B}$, with antigenic structure $(\mathrm{O}$ 1,4,5,12 and $\mathrm{H}$ i:1,2) and $S$. Kentucky belong to serogroup $\mathrm{C} 3$, with antigenic structure $(\mathrm{O} 8,20$ and $\mathrm{H}$ i:Z6). 
Molecular characterization of $E$. coli and Salmonella spp. isolated from birds and humans.

In this study 16 representative $E$. coli from birds, feed, water and human table (21) were subjected for further identification by PCR which successed for confirmation of identified serotypes and detection of virulence genes at specific band for stx1 at base pair 614 , for stx 2 at base pair 779 and for eaeA at 890 bp. PCR success the amplification of E. coli with ratio (100\%) Photograph (1).

Table (7) photograph (1) showed the incidence of virulence genes of $E$. coli strains isolated from some samples isolated from bird, feed, water and humans. O26 showed serotype specific bands of stx2, stx1 and eaeA genes on agarose gel electrophoresis by multiplex PCR, while O91and $\mathrm{O} 158$ showed bands of stx 2 and stx1 genes, in addition $\mathrm{O} 2, \mathrm{O} 44$ and $\mathrm{O} 146$ showed bands of stx2. Bands of eaeA was showed by $\mathrm{O} 1$ and $\mathrm{O} 127$. Molecular detection and characterization of shiga toxin producing E. coli were previously applied by Janben et al. (2001), Farooq et al. (2009), Dutta et al. (2011).

Regarding the virulence genes of Salmonella strains of representative samples isolated from bird, feed and humans are illustrated in table (8) photograph (2). By using m-PCR it was revealed that $S$. Enteritidis, $S$. Typhimurium and $S$. Kentucky have three virulence genes (invA, hilA and fimH genes), in addition $S$. Inganda have (invA and fimH genes), while $S$. Takoradi have only fim $H$ gene. The characterization of Salmonella species by presence of invA gene was previously applied by Cortez et al. (2006) and $\mathrm{Hu}$ et al (2011).

\section{Conflict of interest}

None of the authors of this paper has a financial or personal relationship with other people or organizations that could inappropriately influence or bias the content of the paper

\section{REFERENCES}

Abdeen, E.; Elmonir, W.; Suelam, I.I.A. and Mousa, W.S. (2018): Antibiogram and genetic diversity of Salmonella enterica with zoonotic potential isolated from morbid native chickens and pigeons in Egypt.

Adzitey, F.; Liew, C.Y.; Aronal, A.P. and Huda, N. (2012): Isolation of Escherichia coli from Ducks and Duck Related Samples., 7: 351-355.

Alizadeh, A.H.; Behrouz, N.; Salmanzadeh, S.; Ranjbar, M.; Azimian, M.H.; Jaafari, F.; Zolfagharian, K. and Zali, M.R. (2007): Escherichia coli, Shigella and Salmonella spp. in acute diarrhea in Hamedan, Islamic Republic of Iran. East Mediterr. Health J., 13(2): 243249.

Alvarez, J.; Sota, M.; Vivanco, A.; Perales, A.; Ramón Cisterna, R.; Rementeria, A. and Garaizar, J. (2004): Development of a Multiplex PCR Technique for Detection and Epidemiological Typing of Salmonella in Human Clinical Samples., 42(4):1734-8

Amira, M.; Helmut , H..; Omnia , A.; Herbert, H.; Heinrich , N.; Hafez, M. and Hosny, E. (2017): Occurrence of Salmonella enterica and Escherichia coli in raw chicken and beef meat in northern Egypt and dissemination of 
their antibiotic resistance markers., 957.

Ashraf, A. and Tadashi, S. (2012): Genetic analysis of multiple antimicrobial resistance in Salmonella isolated from disease broiler in Egypt., 56 (4): 254-261.

Ashraf, H.M.; Ibrahim, A.I.; Amal, A.M.; Eid, M.; Julie, S.; Ganwu, L.; Nolan, $K$. and Logue, $C$. (2013): Molecular and Phenotypic Characterization of Escherichia coli Isolated from Broiler Chicken Flocks in Egypt., 57(3):602611.

Bai, L.; Lan, R.; Zhang, X.; Cui, S.; Xu, J.; Guo, Y., Li, F. and Zhang, $D$. (2015): Prevalence of Salmonella Isolates from Chicken and Pig Slaughter houses and Emergence of Ciprofloxacin and Cefotaxime Co- Resistant $S$. enterica Serovar Indiana in Henan, China., 10(12).

Bodhidata, L.; Vithayasai, N.; Eimpokalarp, B.; Pitarangsi, C.; Serichantalergs, O.; and Isenbarder, D.W. (2002): Bacterial enteric pathogens in children with acute dysentery in Thailand: increasing importance of quinolone- resistant Campylobacer. South East Asian J. Trop. Med. Puplic Health., 33(4): 752757.

Braden, C.R. (2006): Salmonella enterica serotype Enteritidis and eggs: A

national epidemic in the United States. Clin. Infect. Dis., 43:512-517.

Cortez, A.L.L.; Carvalho, A.C.F.B.; Ikunob, A.A.; Bürger, K.P. and VidalMartinsa, A.M.C. (2006): Identification of Salmonella spp. isolates from chicken abattoirs by multiplex-PCR., 81(3): 340-344.
Cruickshank, R.; Duguid, J.; Marmion, B. and Swain, R.H. (1975): Medical Microbiology. $12^{\text {th }}$ Ed., Edinburg, London and New York.

Dhanashree, B. and Mallya, S. (2008): Detection of shiga-toxigenic Escherichia coli (STEC) in diarrhoeagenic stool and meat samples in Mangalore, India. Indian J. Med. Res., 128: 271-277.

Dutta, T.K.; Roychoudhury, P.; Bandyopadhyay, S.; Wani, S.A. and Hussain, I. (2011): Detection \& characterization of Shiga toxin producing Escherichia coli(STEC) \& enteropathogenic Escherichia coli (EPEC) in poultry birds with diarrhea., 133(5): 541-545.

Fagan, P.; Hornitzky, M.; Bettelheim, K. and Djordjevic, $S$. (1999): Detection of Shiga-Like Toxin (stxl and stx2), Intimin (eaeA), and Enterohemorrhagic Escherichia coli (EHEC) Hemolysin (EHEC hlyA) Genes in Animal Feces by Multiplex PCR. Appl. Environ. Microbiol., 65 (2): 868-872.

Farooq, I.; Hussain, M.A.; Mir, M.A.; Bhat, M.A.; and Wani, S.A. (2009): Isolation of atypical enteropathogenic Escherichia coli and Shiga toxin 1 and 2f-producing Escherichia coli from avian species in India., 48(6): 692-697.

Guo, X.; Chen, J.; Beuchat, L. and Brackett, R. (2000): PCR detection of Salmonella enterica serotype Montevideo in and on raw tomatoes using primers derived from hilA. Appl. Environ. Microbial., 66: 5248-5252.

Halfaoui, Z.; Menoueri, N. and Bendali, L. (2017): Serogrouping and antibiotic resistance of Escherichia coli isolated from broiler chicken with colibacillosis in center of Algeria., 10(7): 830-835. 
Hanan, M. and Gharabibeh, R. (2004) Rapid and Simultaneous Identification of Two Salmonella enterica Serotypes, Typhimurium from Chicken and Meat Products by Multiplex PCR., 3(1): 4448.

Hassan, H.K.H. and Aml, A.M. (2014): Characterization of Escherichia coli strains isolated from infected pigeons in Assiut province., 60 (142).

Heba, A.A. (2003): Tracing some sources of infection of some zoonotic bacteria among family

Enterobacteriaceae.M.V.SC

(Zoonoses), Fac. Of Vet. Med., Zagazig univeristy.

$H u, Q . ; T u, J . ; \quad H a n, X . ; Z h u, Y . ;$ Ding, $C$. and $Y u, s$. (2011) Development of multiplex PCR assay for rapid detection of Riemerella anatipestifer, Escherichia coli, and Salmonella enterica simultaneously from ducks., 87(1): 64-69.

Janben, T.; Schwarz, C.; Preikschat, P.; Voss, M.; Philipp, H.C. and Wieler, L.H. (2001): Virulence-associated genes in avian pathogenic Escherichia coli (APEC) isolated from internal organs of poultry having died from colibacillosis., 291( 5): 371-378.

Kauffman, G. (1974): Kauffmann white scheme. J. Acta. Path. Microbiol. Sci., $61: 385$.

Kok, T.; Worswich, D. and Gowans, E. (1996): Some serological techniques for microbial and viral infections. In Practical Medical Microbiology (Collee, J.; Fraser, A.; Marmion, B. and Simmons, A., eds.), $14^{\text {th }}$ ed., Edinburgh, Churchill Livingstone, UK.

Kreig, N. and Holt, J. (1984): Bergey's Manual of systemic bacteriology
Vol.1.William and Wilkins, Baltimore, M.D.21202, USA.

Lutful, S.M. (2010): Avian Colibacillosis and Salmonellosis: A Closer Look at Epidemiology, Pathogenesis, Diagnosis, Control and Public Health Concerns., 7(1): 89-114.

MacFaddin, J.F. (2000): Biochemical tests for identification medical bacteria. Warery Press Inc, Baltimore, Md. 21202 USA.

Maysa, A.; Merwad, A.M. and Rehab, E.M. (2013): Prevalence of Zoonotic Escherichia coli and salmonellae in Wild Birds and Humans in Egypt with Emphasis on RAPD-PCR Fingerprinting of E. coli., 11 (6): 781788.

Mazaheri, S.; Ahrabi, S. and Aslani, M. (2014): Shiga toxin-producin Escherichia coli isolated from lettuce samples in Tehran, Iran Jundishapur J. Microbiol., 7 (11): 1-6.

Menghistu, H. (2010): Studies on molecular heterogeneity among Salmonella Gallinarum isolates of poultry origin. M.V.Sc. Thesis, Deemed Univ., IVRI, Izatnagar, Bareilly.

Mohamed, A.A.; Nasser, M.M.; Mowafy, L.E.; Magda, A.A. and Heba, A.A. (2004): Tracing some sources of infection of some zoonotic disease due to some bacteria among family Enterobacteriaceae. Zag. Vet. J., 32(1): 1-14.

Mohammad, L.N.; Samaha, H.A.; Draz, A.A. and Haggad, Y.N. (1999): Salmonellae among birds and human beings., 15 (1): 147-154.

Mondal, T; Khan, M.S.R.; Alam, M.; Purakayastha, M.; Das, $M$ and Siddique, M.P. (2008): Isolation, 
identification and characterization of Salmonella from duck., 6 (1): 07-12

Nagwa, S.R.; Nashwa, O.K.; Mervat, E.I. and Jehan S.A. (2012): Epidemiological and Molecular Studies of Salmonella Isolates from Chicken, Chicken Meat and Human in Toukh, Egypt., 8 (2): 128-132.

Nógrády , I.N.; Kardos, G.; Bistyák, A.; Turcsányi, I.; Mészáros, J.; Galántai, Zs.; Juhász, A.; Samu, P.; Kaszanyitzky, J.É.; Pászti, J. and Kiss, I. (2008) Prevalence and characterization of Salmonella infantis isolates originating from different points of the broiler chicken-human food chain in Hungary., 127(1-2):162167.

Orji, M.U.; Onuigbo, H.C.; Mbata, T.I. (2005): Isolation of Salmonella from poultry droppings and other environmental sources in Awka, Nigeria., 9(2): 86-89.

Quinn, P.J.; Carter, M.E.; Markey, B.K. and Carer, G.R. (1994): Clinical Veterinary Microbiology. Mosby Londen. WCTH, 9LB, England.

Sadoma, A.M. (1997): Salmonella in chicken in connection with human Infection. M.V.Se Thesis. Fac.of Vet.Med. Tanta University.

Se-Yeoun, C; MinKang, Y.; Choi-Kyu, P.;Oun-young, M.; Hyung-K.(2013) :
Prevalence and antimicrobial susceptibility of Salmonella isolates in Pekin ducks from South Korea., 36(5): 473-479.

Scallan, E.; Hoekstra R.M.; Angulo F.J.; Tauxe, R.V.; Widdowson M.A.; Roy, $S$ L.; Jones, J.L.and Griffin, P.M. (2011): Foodborne illness acquired in the United States-Major pathogens. Emerg. Infect. Dis., 1:1-21.

Shah, D.; Shringi, S.; Besser, T. and Call, D. (2009): Molecular detection of foodborne pathogens, Boca Raton: CRC Press, In Liu, D. (Ed) Taylor \& Francis group, Florida, USA, Pp.., 369389.

Shanmugasamy, M.; Velayutham, T. and Rajeswar, J. (2011): InvA gene specific PCR for detection of Salmonella from broilers. Vet. World., 4 (12): 562-564.

Singh, A., Yadav, S., Singh, S. and Bharti, $P$. (2010): Prevalence of Salmonella in chicken eggs collected from poultry farms and marketing channels and their antimicrobial resistance. Food Res. Inter., 43: 2027-2030.

Taha, N.A.A. (2002): Zoonotic importance of entero pathogenic Escherichia coli (EPEC). Ph.D. Thesis, Fac. of Vet. Med. zag .Univ. 


\section{الملخص العربي \\ دور الطيور المنزلية فى نقل اليكروب القولونى العصوى وأنواع السالمونيلا كمسببات مرضية مشتركة}

ط.ب. منى ناصر محملث* ، أ.د. عادل حلمى الجوهرى** ، أ.د. عمرو عبد الفتاح محمد **

* مديرية الطب البيطرى- محافظة الدقهلية

**قمم الصحة والامر اض المشتركة، جامعة المنصورة مائه

ان الدور الحقيقى للطيور والبيئة المحيطة بها فى نقل بعض البكتريا ضمن عائلة الانتيروبكترياسى ماز ال محل الاراسة ـ ولذلك فان الهذف من هذه الدراسة هو تحديد دور الطيور المنزلية كمصدر رئيسى فى نقل البكتريا الى مربى الطيور. ولهذا فقد تم تجميع عدد بـ ؛ عينة من الطيور بمدينة المنصورة والقرى المحيطة بها، محافظة الدقهلية،

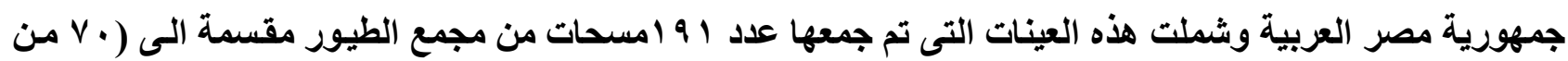

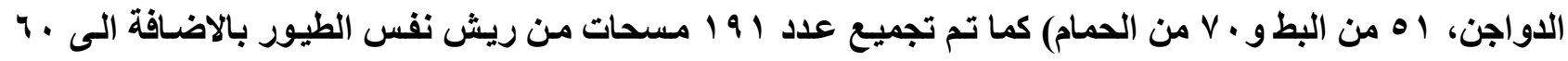

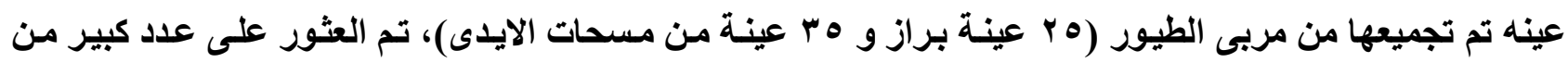
الميكروب القولونى العصوى فى العينات التى تم تجيعها فمثلا تم العثور على الميكروب القولونى العصوى في مسحات

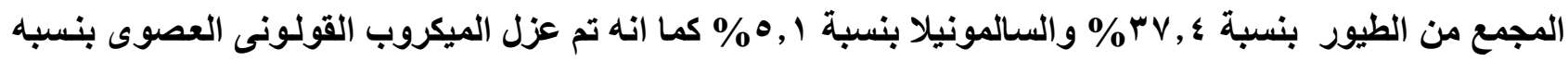

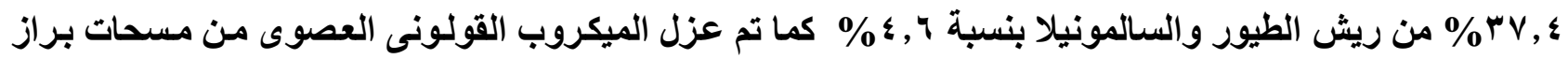

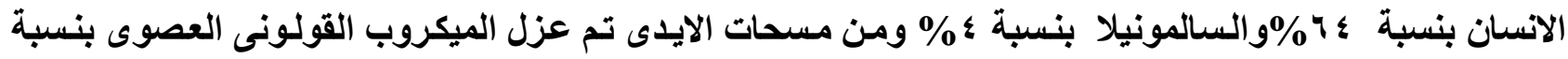

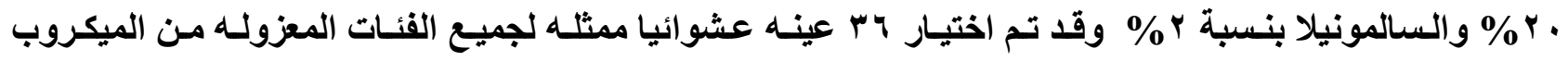
القولونى العصوى وعدد \& 1 عينه للسالمونيلا لاخضاعهم للاختبارات السيرولوجية ليتم تصنيفها وفى نفس الوقت تم تم عمل اختبـار البلمرة المتسلسل للميكروب القولهنى العصبى باستخدام البـادى المتخصص لكسل جين مـن جينـات الضر اوة الاكثر شيوعاوهم (stx2, stx1 and eaeA) وقد تبين وجود جين او اكثر فى عترات الايشيريشيا كولاى

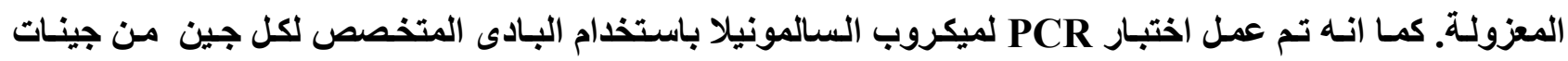
الضرواة الاكثر شيوعاوهم (invA, hilA and fimH genes) وقد تبين وجود واحد او اكثر من هذه الجينـات فى هي

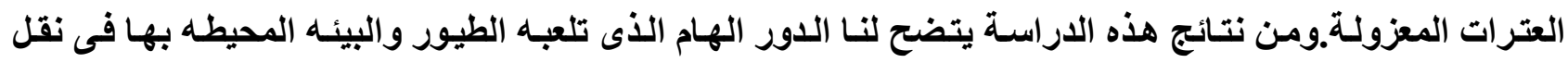
الميكروبات المشتركه التى تفرز الاتتيروتوكسين والتى تؤثر تأثيرا سلبيا على صحة الانسان وقد تم مناقشة الأهمية المشتركة للميكروبات المعزولة وتأثيرها على الصحه العامه للانسان. 